\title{
Public authority and its demons: the Sherbro leopard murders in Sierra Leone
}

\author{
Paul Richards
}

\section{The argument}

Mary Douglas and other practitioners of Africanist social and cultural anthropology in its high modernist mid-twentieth-century form (6 and Richards 2017) were clear that beliefs concerning witches and other occult entities formed an important part of political and juridical processes in much of Africa during the late colonial period in which they worked. Equally, Douglas assumed that much would have been swept away by postcolonial social change (Douglas 1963: 269). Thus, she was shocked on a return visit to the Lele in Kasai Province, Democratic Republic of Congo, in the mid-1980s, after an absence of over three decades, to encounter a witch-finding crusade mounted against local public authorities by two Catholic priests. She inferred from this disturbing experience that persistence of beliefs in demonic forces must be connected to the economic immiseration of postcolonial Congo (Douglas 1999a). Meanwhile, a younger generation of anthropologists was reinvigorating the study of African witchcraft and discovering that it had a strong presence in postcolonial urban areas (Comaroff and Comaroff 1993; Geschiere 1995). Like Douglas, they also pointed to the neglected political and economic salience of the demonic. Since then, the study of populism has become a topic of major concern among political scientists (Laclau 2005; Mudde and Kaltwasser 2017), and we are somewhat better prepared to understand ways in which political actors engage with occult aspects of the popular imagination. Analytically, however, better accounts are needed concerning how such notions are generated, distributed and manipulated (Grijspaarde et al. 2013).

A key analytical problem is that occult notions have no discernible grounding in the material world. People believe in the existence of occult forces for reasons connected to social solidarity and are often prepared to act as if such beliefs were empirically true. Coping with social facts - ones that shape behaviour without having material embodiment - requires an elaborate social philosophy, of the sort that Emile Durkheim sought to provide (Durkheim 1995 [1912]). As yet, social scientists have reached no general agreement on these conceptual underpinnings. There is, however, a growing consensus that they involve performative variables - in which meanings arise out of actions (James 2003; Seligman et al. 2008). For example, there is no readily apparent material advantage to the British exit from the European Union, but the slogan 'Get Brexit done' proved an effective

\footnotetext{
Paul Richards was Professor of Anthropology at University College London, and latterly Professor of Technology and Agrarian Development at Wageningen University in the Netherlands. Now an independent scholar, his recent books include Ebola: how a people's science helped end an epidemic (Zed, 2016) and, with Perri 6, Mary Douglas: understanding social thought and conflict (Berghahn, 2017). Email: paul.richards1945@gmail.com

(C) The Author(s), 2021. Published by Cambridge University Press. This is an Open Access article, distributed under the terms of the Creative Commons Attribution licence (http://creativecommons.org/ licenses/by/4.0/), which permits unrestricted re-use, distribution, and reproduction in any medium, provided the original work is properly cited.
} 
route to power for the current British government. As Durkheim predicted, the action creates the meaning, not least when the action has a ritualized form.

This argues for continued allegiance to Durkheim's late (so-called) ethnographic turn (Richman 2002) as a way to understand how actions generate meanings and thereby create definite social, economic and political worlds. This article is an essay on the performance of public authority in a small part of precolonial West Africa in the throes of colonial occupation, accessed by means of an ethnographic approach. It attempts to convey ways in which public authority played out in occluded polities built on cults of secrecy and plagued by existential insecurity. The aim is to give a better understanding of ways in which public authority is challenged to manage potentially unstable local beliefs in the demonic within the stagecraft of politics.

The actions to be described took place in a portion of the Upper West African coast known in the late nineteenth century as British Sherbro (Figure 1). This territory was a colonial sphere of influence, not a formally constituted colony, and its liminality - neither clearly part of independent Africa nor formally annexed as part of the British colonial empire - is central to the story to be unfolded. While Sherbro remained betwixt and between, the demons of leopard murder flourished; as colonial rule was more firmly institutionalized, scope for the performance of leopardism as political theatre was reduced.

\section{British Sherbro}

The British had established the Crown Colony of Sierra Leone, further up the West African coast, in 1808 (Figure 1), and had made its capital, Freetown, the base of the Royal Navy's Atlantic anti-slavery squadron. The last vestiges of the Atlantic slave trade were uprooted from the Upper West African coast in the 1840s. This freed Bonthe, the main port of British Sherbro, to be a focus of a new and legitimate trade in palm oil, a commodity in increasing demand in Victorian Britain not only as a vegetable oil in soap and margarine manufacture but also for the lubrication of industrial machines, such as railway locomotives. The oil palm grew profusely throughout the coastal plain, which was accessed by four rivers converging on the Jong estuary, and Bonthe had good anchorage for shipping (Figure 1). Much of the palm produce was shipped to Liverpool in steamers that dominated West African produce trade to Britain in the second half of the nineteenth century (Lynn 1992).

The British authorities in Freetown thus had good reason to be deeply interested in Sherbro affairs, given that the colony of Sierra Leone was largely mountainous and lacking in agricultural exports. As yet, however, they were unwilling to impose full colonial control on the hinterland, since that would have required expensive military operations. Instead, they sought to exercise political influence supportive of the export trade in palm produce through the appointment of two British commissioners to Sherbro, Thomas Alldridge and G. H. Garrett, both of whom figure in the story below. Garrett is a lesser known figure, who died in service. Alldridge left a published record of his exploits (Alldridge 1901).

Thomas Joshua Alldridge was an oil palm trader based on Bonthe island until taken into colonial government service by the Colony of Sierra Leone. His diplomatic instructions required him to open contacts with the chiefs of the interior, 


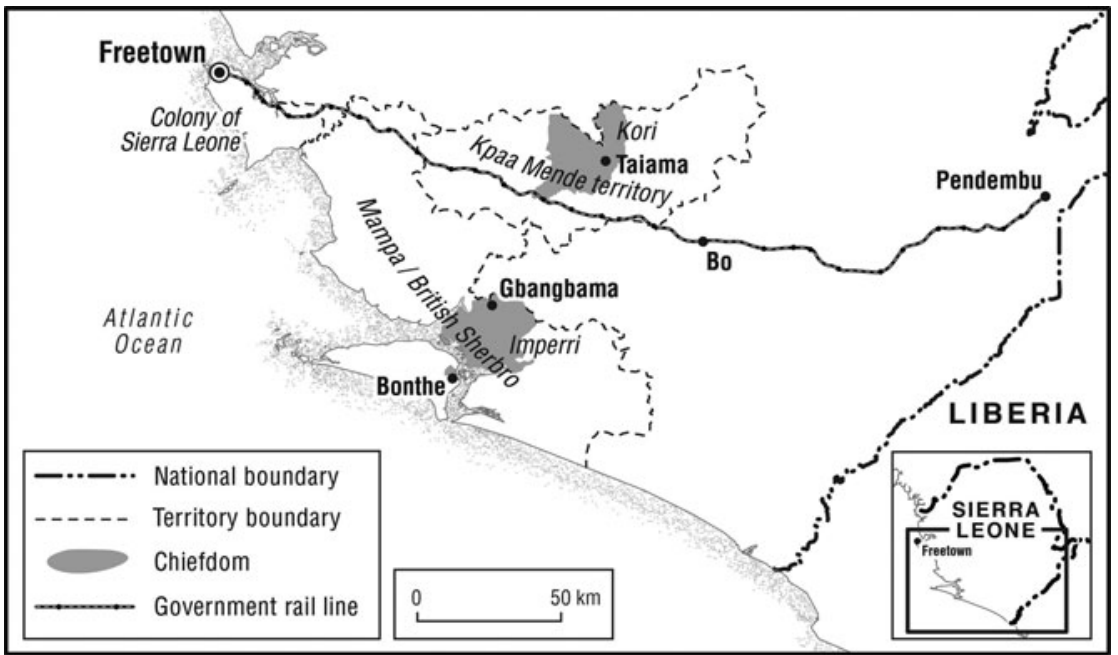

FIGURE 1 Map of the Sierra Leone colony and protectorate showing Sherbro country, Imperri chiefdom and the Kpa Mende polity of Taiama (Kori chiefdom).

many of whom were brought to a conference with the British Governor in 1893, prior to annexation as the Protectorate of Sierra Leone from 1896. A group of chiefs then rose in revolt against British rule in 1898. Whether the rebellion was triggered by loss of sovereignty, new taxation or threatened loss of domestic slaves divided the colonial authorities, depending on how they saw the value of Sierra Leone - as a base for the projection of Royal Navy power in the Atlantic or as an economic asset in its own right. Alldridge belonged to the faction holding the second view. After the rebellion of 1898, the military viewpoint predominated - leading first to the armed occupation of the interior and then to the building of a railway across the newly acquired territory for improved security (Figure 1). Blamed for pushing the interests of commerce too aggressively, Alldridge resigned his commission and left the country.

It is also important by way of contextualization to say something about the ethno-historical character of British Sherbro. Sherbro is a corruption of Seh Bura, the ruler's society name, applied by the British to the Bullom territory of Mampa. His subjects spoke a variety of languages - Banta, Bullom, Themne, Loko and Mende. Banta, Bullom and Themne belong to the Atlantic group of languages in Greenberg's widely accepted classification. Loko and Mende (which are similar, but not mutually intelligible) belong to the south-western branch of the Mande language family, mainly associated with the basin of the Upper Niger. The Bullom speakers have a longer history in the coastal regions around the Sierra Leone peninsula. The Banta and Themne appear to trace their origins to the north and west. Loko and Mende groups are associated by origin with the forests to the east (Figure 1). They first came into the hinterland of Sierra Leone as foot soldiers in the Mane incursions of the sixteenth century.

According to Portuguese and Cape Verdean traders, the Mane were led by Vai overlords from Cape Mount (Jones 1981). The Mende language appears to have spread within Sierra Leone as the common tongue of rank-and-file fighters 
recruited by the Vai from among the forest-edge communities of what is now the Liberia-Guinea border region. That process of incursion finally came to a halt when Mende and Loko fighters encountered other groups with similar military technologies and tactics moving in from the north-west. The interior of Sierra Leone became a campground where intermittently warring groups sought local incorporation and accommodation. Prominent in this process were the Kpa Mende people, a group noted for their military organization who were engaged in the nineteenth century in establishing a common frontier with the Yoni Themne, a rival military polity to the west. An advance guard of the Kpa Mende was established at Taiama (Teyama) (Figure 1). The Taiama chiefs guarded against the Yoni Themne along a common frontier at the same time as they sought to limit British influence in Sherbro to the south.

The materials for this article come mainly from an archival collection of documents made by a Czech émigré historian, Milan Kalous, who was a lecturer at Fourah Bay College in Freetown (where the national archives are based). Kalous published his collection as a series of extracts with file references, but no further editorial apparatus, under the title Cannibals and Tongo Players (privately printed in 1974). His stated aim was to correct a bias of postcolonial historiography in editing out any mention of barbarous acts committed under the influence of these beliefs.

I also make use of two books by Alldridge - The Sherbro and its Hinterland (1901), which documents his interior travels and events leading up to the rebellion of 1898, and A Transformed Colony (1910), written after a visit to the new Protectorate of Sierra Leone during his retirement - and a third book, K. J. Beatty's Human Leopards (1915). Sir Kenneth James Beatty (1878-1966) was an Australian lawyer who sat as a judge in a special court convened at Gbangbama in Imperri chiefdom to try alleged cases of leopard murder in 1913.

In all four sources the possibility of selection bias must be entertained in relation to events recorded (or not recorded). In the case of Kalous, my main source, it would be possible to re-examine the national archives to see the extent to which other materials relevant to his topic have been excluded. I have not had this opportunity, but rely on an important assessment made by the Sierra Leonean historian, the late Arthur Abraham. Abraham knew the Sierra Leone national archives well, having researched Mende politics prior to and after the British occupation. He is critical of what he sees as Kalous' pro-colonial apologetic purposes, and notes some omissions within extracts, but, importantly, he does not accuse him of fabrication or of misrepresenting the body of material as a whole (Abraham 1976). Indeed, he endorses the collection itself as 'masterly' (ibid.: 129). On this basis it seemed to me reasonable to make a provisional assessment of what the Kalous collection might signify. This is something that Kalous himself envisaged an anthropologist might do.

I proceeded by making a computer-searchable database of the items, allowing me to rearrange material by date and topic, and thus to detect epidemiological patterns. Archive references to 'cannibalism' (I will explain the term further below), as selected by Kalous, cluster significantly in a single chiefdom, Imperri, ${ }^{1}$ and peak in the early 1890 s, before British occupation, and then again

\footnotetext{
${ }^{1}$ According to Reed and Robinson (2012), Imperri is a British mispronunciation of mbeli, the Mende name of a tree (Harungana madagascariensis) under which a hunter first sheltered.
} 


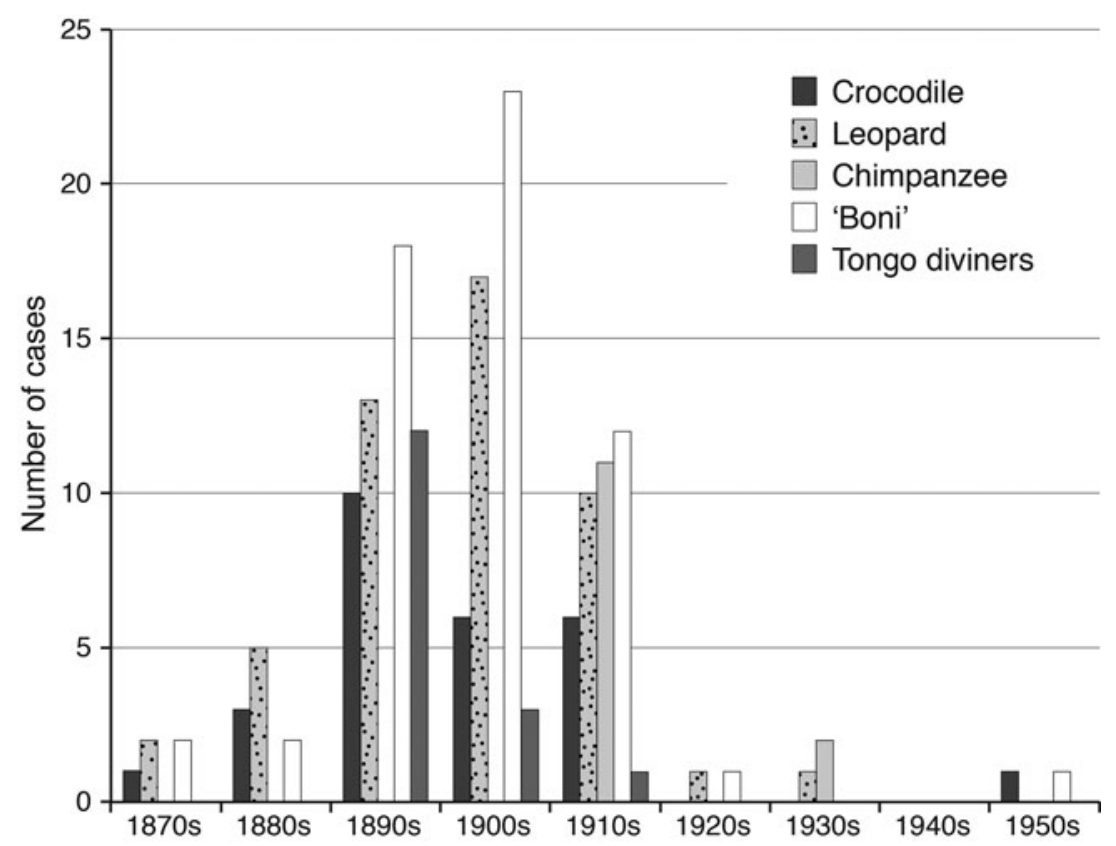

FIGURE 2 Colonial documents relating to leopard murder and similar cases, from the 1870s to the 1950s. Source: Archive materials extracted by Kalous (1974).

in 1911, in the aftermath of an attempt by the British to reorganize local indirect administration by recruiting new and 'progressive' chiefs. Subsequent to the Great War and the consolidation of British control of the Protectorate of Sierra Leone, accusations of leopard killings taper off sharply (Figure 2).

\section{The politics of liminality}

One of the achievements of the mid-twentieth-century social anthropology of Africa was to extend the category of politics to the social worlds engulfed by British colonialism (Fortes and Evans-Pritchard 1940). This was an especially significant achievement in the case of so-called stateless societies (Middleton and Tait 1958). In an influential comparative essay on West African stateless societies, Robin Horton recognized three main types of statelessness among settled peoples and considered the regions at the western end of the Upper Guinea forest as representative of one of these types - societies based on 'the large compact village' (Horton 1985: 106). These village micro-polities might vary in size from perhaps 500 to several thousand people.

The Mende village republics bordering British Sherbro come under this categorization, as do the Bullom chieftaincies within the Sherbro region. Each polity comprised a population of freeborn members of landowning patrilineages, 
claiming rights through first arrival or conquest, who intermarried with other landowning lineages, and a substantial underclass of slaves and clients. The leading men and women of the landowning groups were linked through membership of three sodalities (Poro and Wunde for men, Sande for women). These provided a secure context within which the secrets of the community could be contained (Ferme 2001) - for example, the true history of land settlement in the area. First-comers were deemed to have important specialist knowledge about the land but were not necessarily the most powerful members of the associations.

Poro and Wunde also provided a means through which inter-village cooperation could be applied to matters of collective interest, such as security and trade. Poro directives were used to open and close the collection and processing of the semiwild oil palm fruits that were abundant in all farming areas. This protected the palm groves against over-exploitation but also conserved labour supply for growing rice, the staple crop. The sodalities also served to draw a veil over the very mixed origins of these communities. Typically, one community might be ruled by a warrior who had captured many women and children in battle, and had then settled them in a defensive location behind a system of stockades and ditches. Another community might have invited a warrior to become their chief to protect them from the aggressive designs of other invaders. Two leaders might then form a marriage-based alliance against a third interloper, and so forth. These mixed origins were known to the members of the sodalities while a united front would be presented to the world. The true picture might be evident only in the languages spoken at home - perhaps Banta or Bullom rather than Mende.

A Mende-speaking informant who recently accompanied me through a rather lonely grassland to the east of Taiama was prompted to tell me that villagers had occasionally hunted elephants in the area (a small herd grazed seasonally at the foot of the escarpment of the Kangari Hills). But you could only hunt an elephant successfully, he added, if you first spoke to it in Banta. This is an indication of the likely origins of many local inhabitants, and a mark of the respect in which Kpa Mende chiefs continue to hold the knowledge of the older families absorbed within the community.

The precolonial politics of these communities can be summarized in terms of a scheme of four modes of social accountability proposed by Mary Douglas, building on Durkheim (Douglas 1999b). According to Douglas, all four forms of social ordering are likely to be present in any given social setting but developed to different degrees. Bulte et al. (2018) have demonstrated the applicability of the scheme to an understanding of institutional dynamics in rural coastal Upper West Africa.

The first mode of social accountability is enclave ordering. Enclaves generate a distinctive form of politics (Douglas 2001 [1992]). In the account offered by Bulte et al. (2018: 44), freeborn families of the village republics were bonded by marriage exchanges between exogamous patriclans. This created a lifelong web of mutual obligations, to help with food security, in sickness, and eventually at death. Payment of bridewealth was the price of entry to this enclave world, and freeriders were (and still are) sanctioned in local courts (Mokuwa et al. 2011). Inter-family order was maintained by the leaders of the powerful sodalities into which all members of the community were initiated as young people.

These communities also recognized a (more limited) place for the three other forms of social ordering set out in Douglas's scheme. Individualist ordering was 
mainly evidenced in the activities of some numu waisia (big people) who took part on their own account in war (at times single-handed combat), hunting and trade (Bulte et al. 2018: 39-58). Isolate ordering was associated with those held in slavery or tied down seasonally by the demands of food production. Slavery was often the product of indebtedness. Slaves generated surplus food used in military and mercantile ventures. The slaves at times lived in separate settlements, adjacent to reserves of land. Seasonal isolate ordering was also a common experience for freeborn members of the village republics. Households might leave the village and reside on their rice farms during the main part of the farming season (from May to October) in order to protect the crops that ensured food during the preharvest hungry gap. Hierarchical ordering was developed to a limited extent in the larger centres such as Taiama, a place surrounded by a number of junior or vassal polities. There was little overt bureaucracy, but Taiama showed considerable organizational capacity in being able to forge a regional coalition of chiefs opposed to the British takeover of the hinterland in 1896. Poro, which had a regional aspect (lodges allowed members of other lodges to participate in some meetings), seems to have played a considerable part in coordinating the eventual war against the British.

In this way, a distinctive set of political formations was created, loosely allied by marriage and sodality membership and regulated by leaderships supported in their decision making by divinatory practices. Overt leadership was apparent in public events, such as trade or war, but much lay hidden and subject to occult manipulation. It was this aspect that presented a particular challenge to British commercial expansion into the palm belt of coastal Sherbro in the late nineteenth century. Faced with loss of sovereignty, the leaders of the village republics rose in revolt against the British colonial regime in 1898. After a brusque military response, the British then reconstructed the village republics of the Sierra Leonean interior into a system of paramount chiefdoms for their own purposes of indirect administration (Reed and Robinson 2012). The word 'paramount' had a special interpretation under this British-devised system - it meant that no chief was to interfere in the affairs of any other chiefdom. This nipped incipient hierarchy in the bud. For good measure, larger chiefdoms were then often broken up into smaller units. This, in Abraham's analysis, was how sovereignty was drained from the local administrative system (Abraham 1978). It also increasingly cramped the distinctive mode of enclave politics of which 'leopard murder' was an imaginative projection.

\section{The arrival of 'cannibals' in British Sherbro}

Boni hinda is a phrase in the Mende language meaning 'cannibal business'. ${ }^{2}$ The cannibalism is not for food. Rather, it involves the alleged harvesting of body parts to make a potion known as bofima, which is thought to provide access to wealth and political power. The victim was generally a young person or child. As noted,

\footnotetext{
${ }^{2}$ Abraham (1976) prefers 'leopardism' and its Mende equivalent ksli hinda, but since my discussion also refers to chimpanzees I have used the more general term boni hinda.
} 
TABLE 1

Distribution of cases by district. Source: Archive materials extracted by Kalous (1974).

\begin{tabular}{|c|c|c|c|c|c|}
\hline District & Crocodile & Leopard & Chimpanzee & Boni (unspecified) & Tongomoisia \\
\hline Bo & 1 & 0 & 0 & 0 & 0 \\
\hline Bombali & 0 & 0 & 0 & 0 & 0 \\
\hline Bonthe & 14 & 35 & 0 & 49 & 14 \\
\hline Kailahun & 0 & 0 & 1 & 0 & 0 \\
\hline Kambia & 2 & 0 & 0 & 0 & 0 \\
\hline Kenema & 1 & 1 & 0 & 1 & 0 \\
\hline Koinadugu & 0 & 1 & 0 & 1 & 0 \\
\hline Kono & 0 & 0 & 0 & 0 & 0 \\
\hline Moyamba & 0 & 2 & 0 & 5 & 0 \\
\hline Port Loko & 9 & 5 & 4 & 2 & 0 \\
\hline Pujehun & 0 & 1 & 1 & 1 & 0 \\
\hline Tonkolili & 0 & 1 & 0 & 0 & 0 \\
\hline Unspecified & 0 & 3 & 6 & 4 & 0 \\
\hline Total & 27 & 49 & 12 & 63 & 14 \\
\hline
\end{tabular}

the practice has a distinct epidemiology, being confined mainly (in 68 per cent of cases) to Sherbro country (Table 1).

Most of the cases culled by Kalous came from one chiefdom, Imperri, and are mainly confined to the decades of political uncertainty surrounding the British declaration of a protectorate in 1896 (Figure 2). Reports from elsewhere in Sierra Leone are rare. ${ }^{3}$ Discussing cannibalism, informants will sometimes remark on its association with Sherbro country, and will add that cannibalism is something for chiefs, whereas witchcraft is found everywhere and affects everybody.

In short, and unlike witchcraft, 'cannibalism' (as recorded by Kalous) was highly clustered, both in time and space. It is reasonable to ask whether Kalous' collection displays selection bias. That would depend on his motivation. He states that he felt historians of Sierra Leone were guilty of suppressing evidence of barbarism, but if this was his motive it is hard to see how he strengthens his case by selectively including cases from only one district. If cannibalism was an epiphenomenon everywhere, his selection bias would tend towards a wider spread of cases.

Upper Guinean coastal societies are documented from the days of Portuguese contact in the later fifteenth century. To my knowledge, no mention of human leopard murder has yet been traced in these earlier documents, whereas witchcraft, secret societies, beliefs in spirits, exchange marriage institutions, the administration of justice, and the workings of the poison ordeal as a remedy for witchcraft are all well described (see, for example, Álvares 1990 [c.1615]). 'Cannibal business' is thus not to be confused with witchcraft belief (Grijspaarde et al. 2013). Mende-

\footnotetext{
${ }^{3}$ Leopard murders are also reported from coastal Lower West Africa. Nwaka (1986) and Pratten (2007) document a major outbreak of leopard murder in eastern Nigeria in around 1945. Pratten does not rule out Sierra Leonean influence in the spread of this moral panic.
} 
speaking people have a separate word for the witch - həna. Witchcraft (həna hinda) can cause sickness and unexplained death, but it does not leave physical signs of mutilation. Cannibalism is recognized from its physical manifestations - evidence of a body being cut open, often with scratches resembling the wounds caused by leopards, and the removal of entrails. Furthermore, there is a difference in the way the arrow of blame points (Douglas 1992: 93). In witchcraft cases it is directed horizontally at peers; in cannibalism it points upwards, towards chiefs and elders.

Beatty (1915: 3) traces the first mention of leopard cannibalism to 1854. BJfima was also of mid-nineteenth-century provenance. M. Z. Macaulay, a Sierra Leone trader at Gambia (in Sherbro), informed Alldridge that its introduction into Imperri 'was revenge of Taiama people for a failed arrangement to attack Bambaiya (Gbangbama) about 1875'. Macaulay thought it was a political trick to excite greed and thus to divide the Sherbro people. ${ }^{4}$

The evidence briefly reviewed in this section seemingly provides little support for the idea that cannibalism was a culturally widespread, long-lasting or stable cultural occurrence. The data invite a search for specific, not general, societal causes. And the specific cause proposed here is the threat of land acquisition for palm oil planting.

\section{Demonic forces in defence of land}

In the 1870s, a Krio merchant from Freetown, S. B. A. Macfoy, set up palm oil buying operations in Sherbro, initially as an agent for the firm Callender, Sykes and Mather (Fyfe 1962). He quickly became a trader on his own account, and his business grew to the point where he owned as many as ten produce-buying stores. In the 1880 s his operations were on a scale that justified chartering a steamship to transport his produce to Europe. He had ambitious plans to acquire land for plantations. But a trade recession, and increased competition from European firms, rendered him bankrupt in 1890, and he was forced to mortgage his factories to pay off a large debt.

He died sometime before 1895, the year in which Alldridge reports (on 24 August) that a new owner (a Mr Lewis) was in business at Gbangbama (Imperri chiefdom), trading for 'the estate of the late Mr. Macfoy' (Kalous 1974: [49])..$^{5}$

The palm oil trade appears to have stirred up local conflict. As early as November 1879, Macfoy had written to the British administration in Freetown suggesting immediate steps be taken 'to make peace between Mendis and Imperry [sic] Country' (Kalous 1974: [165]). This was less a conflict between ethnic groups than a struggle over different visions of the future. Some chiefs

\footnotetext{
${ }^{4}$ According to Macaulay, 'The object of the Taiama people [in] spreading ... [the] "medicine" [was to] compel the Imperri people to kill themselves ... People formed themselves into Secret Societies ... providing victims from their own families and relations ... 15 years ago' (Kalous 1974: [36]).

${ }^{5}$ Due to lack of space, I refer to cited documents by the numbers assigned to them in the Kalous collection and listed in Cannibals and Tongo Players of Sierra Leone (shown here in square brackets), rather than providing full details of each document.
} 
were enthusiastic about the new international trade; others were more mindful of the collective values of the enclave.

The chief of Imperri was known as the Sokong and appointed by elders of a sodality (secret society) known as the Feffeh. Alldridge witnessed a coronation and described the public ceremonial in which the ruler was required to forget his family and rule on behalf of the community, or probably more specifically on behalf of the inter-family alliance of family elders constituting the upper echelon of the Feffeh (Alldridge 1910: 270). Specifically, the Sokong was enjoined not to advance his own interests by making war.

Macfoy chose to dive into this delicately poised field of enclave political relations by suggesting to the British the need for an arbitrator (namely, himself) to obviate conflicts associated with increased trade. Subsequently, he began to lobby the British on behalf of local interests, having built a position through gifts and loans to some society elders.

The British administration quickly became anxious about his undue political influence. In 1879, J. C. Leggie, the acting Civil Commandant of British Sherbro, refused to have Macfoy broker between chiefs and the British government (Kalous 1974: [166]). A further report of 1886 to the Colonial Secretary in Freetown directs attention to 'Macfoy's dangerous influence over the Chiefs in Sherbro and adjacent districts ... obtained by promises held out and large presents made'.

In Bompeh country, Macfoy was known as 'Governor' and was said to 'suit policy to himself, ignoring other Native Traders and Government' (Kalous 1974: [167]). This influence was the subject of local complaints. In January 1887, Chief Kahtegbeh of Yangalloh stated that the country now 'belonged' to Macfoy, given that Chief Beah Boom had taken a mortgage from Macfoy and pledged land in return. Nudging the British on their colonial ambitions in Sherbro country, Kahtegbeh notes that Beah Boom offered the land to Macfoy 'because he does not wish [any] white man to take this country' (ibid.: [169]).

In a further communication, Kahtegbeh supplies details of the original mortgage. Beah Boom had taken cash and offered land because he needed to pay his lawyer ('Lewis' - presumably Sir Samuel Lewis QC) for defending his son in Freetown on a criminal charge. Macfoy later sold this land to the brother of the lawyer (presumably the 'Mr Lewis' Alldridge reports as having taken over the deceased Macfoy's business assets) (Kalous 1974: [171]).

Chief Gbannah Bungay, the son of Beah Boom (who by this time had died), then complained to the Commandant in Sherbro that another chief, Bassine (or Bassin), was threatening Macfoy with war due to the fact that land had been mortgaged. Bungay believed, however, that Macfoy 'was in the right because late Bah Bome [Beah Boom] gave him the country with consent of all the chiefs' (Kalous 1974: $[169,170])$.

Tensions continued to rise. Commissioner G. H. Garrett, in Bonthe, wrote to the Colonial Secretary in Freetown on 20 February 1892 to complain that 'trouble in Imperri ... [has been] caused by Mr. S. B. A. Macfoy of Jamaica [factory]' because 'he has bought up a great portion of the country, and [is] giving the occupiers of many villages notice to quit' (by violent intimidation) in places where they 'have lived in some cases all their lives' (Kalous 1974: [173]).

What Macfoy planned to do with the land is not reported (apart from selling some of it to ease his own debts). Martin Lynn notes that adverse trading 
conditions in the 1890s forced Krio palm produce traders to adapt, either by aspiring to become planters, or by 'downsizing' and becoming small-scale 'country traders' (Lynn 1992). Macfoy may have been raising capital to achieve the first outcome.

However, he was not the only person in Imperri with planter ambitions. Daniel Flickinger Wilberforce, born in Sherbro but brought up and educated in the USA, had returned to the region as a pastor with the United Brethren in Christ (UBC). The UBC had links to the abolitionists defending the Amistad mutineers before the US Supreme Court (Jones 1987) and established a mission in Sherbro when some of the Amistad group (including their leader, Sengbe Pieh) returned to their homeland after the trial was successfully concluded.

Wilberforce complained to the British about Macfoy, claiming that some of the land that Beah Boom had pledged to Macfoy belonged to his own family, and on this land he intended to develop mission-related agricultural activities. The UBC strongly emphasized education in practical arts.

On 29 September 1890, Wilberforce also wrote a letter to J. C. E. Parkes of the Department for Native Affairs: 'You have doubtless been made aware of the late practice of Chiefs in various sections of Sherbro, in case of fines for misdemeanors, to dispose of by mortgages and otherwise, lands in various portions of the country, which in many cases they had no right to do without the consent of particular heirs. Those heirs can now maintain their rights [only?] by resorting to arms' (or by an appeal to British justice). He is an heir to such lands and wishes 'to use same for ... the Encouragement of Agricultural and other enterprises'. Wilberforce then makes an explicit request; he wants Parkes to institute an inquiry into 'the ownership of lands in Impereh [sic] and the power to dispose of the same' (Kalous 1974: [226]).

Imperri elders, however, were not prepared to wait on British justice, fearing that the administration was generally in favour of an emergent market in land in the oil palm belt. Land acquisition posed an existential threat to the enclave political system and its interlocking alliances between landholding groups. Sodality elders hit upon occult invention as a way to block further attempts to acquire family land. They began to insinuate that those seeking land were capable of 'cannibal' murder and sought to create facts on the ground when hints were not enough.

The first target was Macfoy. An opportunity arose from the unexplained death of a child in Gbangbama, the headquarters town for Imperri chiefdom nestling in the Imperri Hills. The child came from Wilberforce's household.

The Imperri Hills constituted a small island of tropical high forest surrounded by a sea of intensified agricultural activity stimulated by trading activities in Bonthe. The forest retained a small population of leopards on the brink of extinction. As sometimes happens, half-starved leopards began to stalk children in the nearby settlements. One of them killed the child from Wilberforce's household. Wilberforce hurried to Gbangbama to ascertain what had happened and to report the death to the chiefs, as custom required. He was asked to pay a sum of money to allow the case to be investigated.

The chiefs had now spotted their opportunity to undermine Macfoy. Wilberforce was asked to double the investigation fee because the elders suspected the child had been killed by leopard cannibals and wanted to send for diviners to provide confirmation of occult crime. The tongo gbsmoisia (tong people) were diviners specialized in the detection of thieves and witches, and Taiama had a 
reputation as a centre for persons of this profession. Chief Gbannah Bungay, Macfoy's associate, who had been busy concluding the land deal on behalf of the Freetown trader, took a leading role in inviting and paying for this visit, perhaps to assert that he had nothing to hide. Those opposing Macfoy meanwhile planned to induce the diviners to point the finger of guilt at Chief Bungay himself. In the absence of any written conveyance, they would then rid themselves of the chief witness to Macfoy's land claim.

In former times, by Bullom custom, Bungay could have offered to prove his innocence of antisocial occult activity by drinking sasswood. A decoction of the root of the bush Erythrophleum guineense acts as an emetic but poisons those who fail to respond to the stomach irritant stimulus (Neuwinger 1996). It is, in effect, a lottery. To survive drinking it confirmed innocence of occult manipulation for life. If bold enough to volunteer to take sasswood and live, Chief Bungay would have confounded his enemies at a stroke. However, the British had banned the use of the poison ordeal. A potential avenue of escape was blocked. The Tongo play was an alternative, but more expensive since it involved human judges. Diviners could be bribed - this was perhaps the reason why Wilberforce had been asked for more money.

The diviners from Taiama duly arrived, and the event arranged with Chief Bungay's help commenced. A bonfire was lit, and the dance began. As the dance reached a climax the tongo gbemosia then pointed to those their medicine indicated were cannibals. The outcome was as shocking as it was surprising. Chief Gbannah Bungay was among the first to be detected and burned in the effervescence of the dance.

This dramatic event could not be hushed up. Alldridge himself came to investigate and to report to the Governor in Freetown. According to a subsequent deposition by lawyer Lewis (4 March 1892): 'Gbannah Bungay was killed not because he was a human leopard but because the Chiefs had said he had sold the country to Mr. S. B. A. Macfoy and that by Bungay's death Mr. Macfoy might lose his claim to the country.' Three other vendors had also been 'pointed' and burned, 'the Chiefs [erecting] a funeral pyre for Tuah Yeamie [because] he [also] was one of the witnesses to the conveyance from Gbannah Bungay to Mr. Macfoy'. Lewis adds that the tongo gbemsisia and chiefs 'managed somehow in giving the Imperri people the erroneous idea they were authorized by the Government to repeat the practice' (Kalous 1974: [200]).

This 'erroneous idea' evidently derived from Wilberforce's role in providing the money to bring the diviners from Taiama to Imperri. Potentially, this put him in a bad light with the colonial authorities. Upon hearing that the chiefs had told the acting Queen's Advocate that he had 'sent to call down the Tongo men from Mendi country', Wilberforce felt constrained to give his motivation.

In a letter of 21 October 1890 to the Governor in Freetown (Sir James Shaw Hay), Wilberforce states that in November 1889 he had been called to Gbangbama because 'a boy [of his] had been caught by cannibals' and that in consequence the chiefs had 'imposed a heavy fine upon my people', whereupon he paid the chiefs the 'two heads of money' to make an investigation. When he 'learned that they had called down their country detectives', he interested himself 'in the palaver so as to prevent extreme measures until we could by a fair examination of those pointed out or accused, be satisfied that they were indeed guilty' (Kalous 1974: [227]). Alas, the oracle took its own course. 
Lacking witnesses to his land deals, Macfoy resorted to enforcing his claim with guns. Wilberforce was equally quick to complain about this to the British authorities. In a letter written for himself and the chiefdom speaker, Forney Vanjawah, Wilberforce notified Garrett on 1 September 1892 that Macfoy had come to Gbangbama with 'a great deal of gun and cannon firing' demanding payment of the sum of money given to the late Beah Boom, 'for which the country had been given as security'. Since the chiefs could not pay, they asked that Macfoy 'should continue to hold the country and rule it as he had been doing all along'. But this went against Wilberforce's interests, since it involved lands north of the Gbangbama River that were his 'acknowledged possessions' (Kalous 1974: [175]). Recourse to the colonial courts would be of no help. Macfoy boasted that 'with his money and lawyer he can defeat any attempt against him'. Wilberforce concluded that reversion to local forensic methods was his only remedy. Garrett then reported to Freetown that the chiefs, 'with the Revd. Wilberforce', were using their 'utmost endeavors to arrest the socalled cannibals', having 'begged hard that they might be permitted to suppress it in their own way' (ibid.: [45]).

When Alldridge confirmed the burnings, the British felt impelled to intervene. But instead of moving against the alleged cannibals, the Freetown authorities opted to prosecute the diviners 'and such chiefs as had taken an active part in the burnings' at Gbangbama. The rationale of the administration was supplied by the acting Governor, Colonel A. B. Ellis, a professional soldier, amateur anthropologist, and author of three books on African religion. He noted that, although a secret leopard society had existed for about twenty-five years in Sherbro district, the events at Gbangbama bore none of the distinctive marks of human leopard murder - 'in no case has any part of the body been missing'. Additionally, 'the murders in 1890 only commenced after the Tongo-people had come into the country'. His conclusion was that the leopard murders were not committed by a secret society but by the tongo diviners themselves to create a demand for their services as witchfinders (Kalous 1974: [204]).

Shifting the focus of guilt onto the witchfinders was not good news from the local point of view. It risked letting Macfoy off the hook. Gbannah Lewis, the Bai Sherbro (i.e. Bullom overlord), wrote to Garrett to get back to the main matter in hand - who holds the land? He pointedly asked if there were two (colonial) Governors in Sherbro, since Macfoy was saying that he was 'the owner of the Country' (Kalous 1974: [174]). The irony in the question eluded the recipient. A minuted note stated:

Imperri is decidedly within British jurisdiction but this in no way affects the legitimate claims of anyone to the lands therein and if any such lands have been legitimately transferred to Mr. S. B. A. Macfoy he is within his right in claiming them, but if not their remedy lies in the Courts of the Colony.

So Bai Sherbro was now forced to make his complaint more directly - which he did on 21 December 1892. Macfoy had incited some of the king's subjects to sell 'part of my land' which did not belong to the sellers, and they now 'begged the king's pardon since they had no lawful rights' (Kalous 1974: [176]).

It thus becomes clear that we are in the midst of a major land dispute, caused by Macfoy's mortgages and ambitions to plant oil palm. The conflict was made worse 
by the fact that there was ambiguity over the legal rules prevailing - whether African or British. Furthermore, the issue was more than just the selling of some parcels of land. An entire subsistence way of life was at stake, because if families had no land they could not participate in the dense network of marriage and labour exchanges at the heart of the local rice-planting system. If there were human leopards (as distinct from natural accidents in the bush), these were the epiphenomena of the chaos visited upon enclave politics by one family trying to sell its stake, thereby undermining a carefully balanced system of land, labour and marriage exchanges on which the continuance of the village republics depended. Leopardism is a specific new kind of straight banana intended to build a local consensus for wresting back control of a system of social accountabilities brought into jeopardy by the advent of land acquisitions built on the adoption of British administrative ideas about land and property rights.

\section{A 'British' chief falls by his own weight}

These local quarrels were now overtaken by larger events. In 1896 the British absorbed Sherbro into the new Protectorate of Sierra Leone and were then confronted with two uprisings - the so-called Hut Tax War of 1898. The imposition of colonial taxes was only one factor; the loss of chiefly sovereignty was another. The chiefs feared that colonial law would deprive them of their farm slaves, a major economic asset. The events had two distinct focuses: one in the north of the country, led by a warlord Bai Bureh; and another in the south comprising an alliance of rebellious Mende and Bullom chiefs. Rebellion elicited a vigorous British military response, and a top echelon of elders held to be most responsible for the insurrection was then removed by executions and banishments.

Alldridge (1901) saw the root of the trouble in the British challenge to the power of the sodalities. The British ban on Poro, he noted, 'broke down an old time custom': namely, the power to embargo trade in oil palm (ibid.: 305). 'Custom', however, was more durable than Alldridge imagined. Governance by sodality was a 'total institution', permeating all areas of society. Other shadowy figures quickly stepped into the vacancies and enclave ordering was quickly rebuilt.

Having little or no understanding of the politics of the enclave, the Freetown administration looked for new, more 'enlightened' chiefs as the face of public authority in a reorganized protectorate administration. This was the policy of 'indirect rule', where leading local figures (many of them traders) were recognized by the British colonial rulers as agents responsible for maintaining local order and were granted an official mace of office (known as a staff).

One of those who stepped forward as a British-recognized paramount chief, endorsed by the Governor of Sierra Leone himself, Sir Frederic Cardew, was none other than the Reverend Daniel Flickinger Wilberforce. Freed from his rivalry with the late S. B. A. Macfoy, Wilberforce appears to have assumed that, as a son of the soil, he would have better fortune in acquiring and developing land for palm oil. But he was soon to learn that the politics of the enclave, when under existential threat, has a tendency to consume its own. 
Working behind the scenes, Sherbro elders set about destabilizing Wilberforce with a clearer knowledge of what the British would and would not tolerate in terms of local custom when it came to land issues. The poison ordeal and witchfinders were out of the question. But leopardism remained an option with political potential. Transfixed by the presumed role of Poro in coordinating the 1898 rebellion, the British protectorate authorities were much more amenable than had been Colonel Ellis to the idea of a conspiratorial conclave of clandestine leopard murderers.

Cannibalism accusations surged in coastal districts that were more highly integrated with export markets. With 'country methods' of settlement now proscribed, the protectorate authorities found they had inherited a substantial backlog of cases awaiting trial, especially in Imperri chiefdom. This meant that the government took over responsibility for identifying occult crime from local specialists such as the tong gbemoisia. Henceforth, British justice would both diagnose the crime and prescribe the punishment. This provided a new set of opportunities for those seeking to protect the enclave from land acquisition. They now needed only to compile sufficient circumstantial evidence of occult crime to persuade British judges to intervene.

Obtaining the evidence was not too difficult. There were still leopards around, to provide a pretext. Any accident to a child in the bush might serve. It was also possible, as the Krio lawyer Sir Samuel Lewis remarked in regard to the Macfoy case, that murders could be specifically undertaken for the purpose of framing the victims of this class of political masquerade.

Confession or contradiction were the main evidential grounds for determining guilt, and plea bargaining was allowed. The ultimate penalty was death by hanging. If several people were accused, at least some were likely to 'confess' on a plea bargain to save their lives. Since the accusation was 'conspiracy to murder', those who continued to maintain their innocence were then much more likely to be found guilty by the British judges. In a dispatch to the Secretary of State for the Colonies dated 9 July 1913, summing up the measures taken to 'deal with unlawful societies in the Protectorate', Governor Merewether argued that 'all attempts to provide corroborative evidence [prove] fruitless [due to] a very strong oath of secrecy having clearly been imposed' (Beatty 1915: 120). From the perspective of the enclave elders, colonial law could be manipulated to punish local commercial actors for their suspected untoward greed (Figure 2).

Chief Wilberforce was prominent among several Sherbro chiefs entrapped in this way. He stood trial for alleged complicity in leopard murder twice - in 1905-06 and again in 1912-13 (Beatty 1915; Whyte 2016). In the first case, he managed to persuade the authorities that he was an American citizen and was tried by a jury of his peers in Freetown under Colony Law; the case was dismissed. In the second case, he was accused after a protectorate ordinance banning leopardism and other forms of cannibal murder passed in 1909. The second trial took place in Gbangbama in 1913 as part of a court of special commission set up to clear a backlog of 'cannibalism' cases. It turned out that Wilberforce was not American but a protectorate subject, and he was no longer offered the opportunity to plead before a jury.

The dualities of his lifestyle counted against him. Wilberforce combined his mission work with considerable local business activity and (unknown to his 
superiors) maintained an extended family of several wives and their children. The mission backed him strongly in 1905-06, and with good lawyers he had no difficulty in securing acquittal. But his enemies in Sherbro country persisted and managed to implicate him in this second case, under protectorate law, and this did not go so well.

By the time his case was scheduled, one of the judges of the special court, the former acting Attorney General A. van der Meulen, was on leave; he was replaced on the panel by an adjudicator with a military background. Van der Meulen was a sceptic concerning cannibalism, noting that much of the evidence was hearsay and insisting that better detective work was needed to improve the quality of evidence. His fellow adjudicators appear not to have shared his doubts. The defence sought to prove the alleged victim never existed. The judges were more impressed by circumstantial considerations, suggesting that Wilberforce had been close to the scene of the alleged crime, whether attending to business or family matters, when his mission managers supposed otherwise. The court decided he was guilty and with that the Sherbro elders had their man.

Perhaps sensing that they might have been played, the judges baulked at the idea of sending a missionary to the gallows for such a 'primitive' crime, and the sentence was commuted to exile. Later, Wilberforce seems to have quietly returned to Freetown (Whyte 2016). Others accused before the tribunal were not so fortunate. Six of the accused in the so-called Imperri case were found guilty and executed by public hanging, which duly took place in Gbangbama on 18 April 1913 (Beatty 1915: 42).

For a short while leopard murder was something of a legal sensation - an African institution adjudicated by European judges. Cracks in the explanatory edifice rather quickly began to appear, however. A major setback was when the avatar was found to have jumped species - from leopard to chimpanzee. The British had duly added a putative conclave of shape-shifting chimpanzees to the list of proscribed secret societies in 1912 (Beatty 1915: 126), but the purpose of 'cannibalism' was unclear, since chimpanzee attacks generally resulted in wounding, not murder (Richards 2000). This reinforced the views of those inclined to offer naturalistic explanation. Two leopards were shot within a mile and a trap installed 'within yards' of the courthouse at Gbangbama while the proceedings were under way (Beatty 1915: 43). One cannot help but wonder whether someone with a sense of irony had perhaps installed the leopard trap as a hint to the British rulers of the new protectorate not to take enclave political masquerade too literally.

\section{Discussion and conclusion}

Cases of boni hinda, mainly confined to the betwixt-and-between world of British Sherbro, declined sharply after 1918. Increasingly, British administrators realized that habitat encroachment changed the interaction between animals such as leopard and chimpanzee and human co-occupants. This supported the idea that animal attacks were real and not demonic. District officers also began to cast a sceptical eye over the policing of cannibalism cases, and to discount confession extracted after lengthy periods of incarceration. 
Technical departments had been founded before the war but never properly staffed. ${ }^{6}$ The agriculture department established at Njala in 1912 received its first scientific officers with research training in the mid-1920s. A colonial forest department was founded in Kenema in 1909 and became engaged with sciencebased forest protection from the 1920s. The establishment of a rice research station at Rokupr in 1934 neatly encapsulates this shift in colonial perspectives in relation to science and governance. When a station at Rokupr was first mooted, the Colonial Secretary disputed the need for scientific crop improvement, arguing that a prison farm would serve better. Convicts could be taught how to grow crops and disseminate their knowledge in their villages on release. But advocates of genetics-based plant breeding won the day, even if it took more than a decade for experiments at Rokupr to bear fruit due to lack of understanding of soil variations in the main experimental plot (Richards 1985: 26-7).

In Nigeria, the largest British protectorate in West Africa, developments in colonial policy relating to the oil palm sector were decisive. Governor-General Sir Hugh Clifford rejected the plantation model for oil palm development in 1920, and Gold Coast and Sierra Leone followed suit (Richards 1985: 20). As major British palm oil importers, Lever Brothers turned their attention to acquiring plantations in the Belgian Congo (coincidentally opening a path to the field for the young Mary Douglas). Palm oil in British West Africa was reserved as a crop for indigenous smallholders. With enclave land now secured by protectorate policy, what, then, was the need to stage the masquerade of cannibalism?

Accordingly, few cases found their way into the courts, the archives and Kalous' collection after 1918 (Figure 2). To all intents and purposes, human leopards were extinct. Community land appropriation was no longer a threat.

Recently, however, the threat has returned. Large-scale external acquisitions of land for oil palm plantations resumed in Sierra Leone from 2008, with encouragement from development donors and a worldwide surge in demand for biofuels (Ryan 2018). Land remains the basic asset of enclaved communities, and its expropriation is as controversial as it was at the onset of British colonial rule. This implies the possibility of the revival in the twenty-first century of masquerades of community resistance in response to the threat of land acquisition.

It is a mistake to understand the performative masquerade of threatened enclaves as a kind of tomfoolery. Leopardism was more than knee-jerk barbarism, to be reduced to racist comic book images of wild Africa. ${ }^{7}$ We need a better explanation of what made the enactment of the masquerade of leopardism speak to the beleaguered enclavists of British Sherbro than to assume that gullible people were taken in by tall stories.

Both Durkheim and Douglas demand an explanation in which mythic commitments and performative strategies are linked to facts of social organization. A supportive account in these terms might run as follows.

The village republics of British Sherbro were bonded into enclave organization by inter-family marriage exchange and governed by a small group of reclusive sodality elders organized internally along cooperative lines. Executive authority

\footnotetext{
${ }^{6}$ On the growth of science in British Africa in the colonial period, see Tilley (2011).

${ }^{7}$ 'Leopard men' passed into popular culture in Europe via comic book literature in the 1930s (Jannone 1995).
} 
was otiose. The interlocking circle of cooperation was cautiously maintained. Enclaves are vulnerable to the question posed by Joseph's brothers: who made you to rule over us?

For this reason, Douglas (2001 [1992]) suggests, enclaves show a preference for lotteries as tools of governance. They are anonymous in their working and random in their effects. Resentment is averted and mutualities are maintained. Leopardism was a lottery. It took its bearings from the earlier poison ordeal. This has a long history of widespread use as a mechanism for resolution of conflicts generated by suspicion of witchcraft. One consequence of British supervisory presence in the Sherbro district, however, was the ordeal's suppression. Alternatives were sought. Taiama, in its emergent role as a coordinator of opposition to the expansion of British rule among neighbouring enclave-organized groups, provided one such option. Diviners used a form of dancing to identify human leopards as threats to enclave social cohesion posed by the land acquisition activities of Freetown merchants.

Real, man-eating leopards offered a model for community-destroying acquisitive greed. It was perhaps not hard to persuade a local audience that chiefs bent on mortgaging family land without regard for the community consequences could be pictured as human leopards. The threat of being exposed as a human leopard during a divinatory dance was perhaps initially meant as a warning. But the process got out of hand. Performative processes have a dynamic of their own, and outcomes are not always easy to manage. Unlike the poison ordeal which it replaced, the new divinatory process could be corrupted. Factionalism entered in, hugely increasing the uncertainty of outcomes, with the new oracle sometimes consuming its own.

Not understanding the social anxieties driving leopardism, the British sought to throw out the dancing lottery and to include the detection of cannibalism within their own system of criminal jurisprudence. They thereby accumulated a growing backlog of unsolved cases, resulting in the 1913 trials. The results of the deliberations of the Special Court were self-evidently unsound, being based for the most part on confessional self-incrimination extracted under conditions of lengthy imprisonment and torture. A crisis of credibility threatened colonial justice but was thrown into temporary abeyance by the unpredictable personnel redistributions associated with the Great War. Beatty, the documenter of the hybrid process through which British justices adjudicated the affairs of an (alleged) African sodality, was himself posted to the Dardanelles even as his book, Human Leopards, was being prepared for the press (Beatty 1915).

When British colonial administration resumed with full strength after the hiatus of the Great War it was more securely entrenched, and land concession hunters were rebuffed. A British administrative cadre with some scientific expertise was increasingly sceptical towards allegations of occult intrigue. As a result, leopardism was no longer so effective as a performative strategy to render economic grievances justiciable. Nor was the land under so much threat, after an Africa-wide shift in British thinking, assigning responsibility for cash crop development to peasant proprietors. Local political energies were channelled to other ends, including the eventual struggle for national independence.

Nevertheless, a fear of boni hinda lingers in the collective imagination in rural southern Sierra Leone, and occasional accusations crop up today. How are these recurrences to be explained? As a field anthropologist working over 
several decades in Kpa Mende communities on the fringe of the Taiama polity, my own experience is that boni hinda is recognized by chiefdom authorities because the national government holds them responsible for any local upwelling of disorder. An accusation can thereby be used by troublemakers to create a local scandal, in order to pursue other grievances.

I can offer a concrete example from my own fieldwork. One of my friends in the village was accused of being a cannibal four times in his lifetime. The real reason (I was told) was that he had once killed a child born to one of his wives after an affair. He successfully hid the murder, but the family of the wife never ceased trying to exact revenge. The case was dropped on all occasions for lack of evidence, but not without the man paying dearly each time in impromptu fines. But I should add that he is the only person I know to have been accused of this crime. It is not a common occurrence.

There is also one prominent latter-day instance of cannibalism consistent with the idea that this form of populist political theatre can still be pressed into use in conditions of extreme political flux. This occurred in October 1977, after a disputed election in which the president of independent Sierra Leone, Siaka Stevens, was struggling to impose a one-party constitution on the country. The charge of cannibalism was brought against some of Stevens' most determined opponents, who were then executed for an alleged atrocity the international community struggled either to comprehend or to protest. Perhaps not by accident, the victims of this hideous political stitch-up were from Taiama.

What, then, are the broader lessons of the political performativity described here? The first is that communities have more powerful weapons against the forces of social dissolution wielded by international capitalism than is sometimes recognized. A clear instance is the recent conversion of the British Conservative Party from Thatcherite neoliberalism to a concern with levelling up neglected post-industrial communities. Whether human leopards or straight bananas, populist performative politics captures attention.

Second, more analysis should be directed to performative strategizing around the manipulation of community anxiety - the 'dark side' of populist politics. This is an inescapable element of public authority, and analysts need to recognize its society-shaping potential, as Durkheim argued. But the underlying problem of community versus profits is not easily solved. In Sierra Leone, the current challenge posed by land acquisitions for palm oil production seems likely to have profoundly destabilizing consequences once more. Leopardism is unlikely to return, but new mythic challenges are a recurrent possibility as a way of mobilizing communities overcome by deep disquiet at the activities of powerful outsiders motivated by competitive individualism.

How should these underlying conflicts of interest be addressed? In her centenary year it might be timely to revert to the advice given by Mary Douglas, perhaps the greatest social theorist to be consistently inspired by African social realities. Her view was that social conflict is an inescapable element of the human condition, and that there are no neutral analytical standpoints, but that it pays to inspect carefully and with respect the organizational moorings of the various conflicted social viewpoints. Demonization is an ever present possibility, but it helps no one to reach for demonology as explanation. Light needs to be shed not only on human leopards and straight bananas but also on the underlying social 
grievances sustaining such beliefs. In short, the path to intercommunal peace is paved with careful ethnography.

\section{Acknowledgements}

The preparation of this article was supported by the ESRC Centre for Public Authority and International Development (CPAID) based at the London School of Economics and Political Science (grant code number ES/P0080381/1). The author also wishes to thank three anonymous reviewers - one for CPAID and two for the journal - and Professor Perri 6 for their very helpful remarks.

\section{References}

6, Perri and P. Richards (2017) Mary Douglas: understanding social thought and conflict. New York NY and Oxford: Berghahn Books.

Abraham, A. (1976) "Cannibalism" and African historiography' in Topics in Sierra Leone History: a counter-colonial interpretation. Freetown: Leone Publishers.

Abraham, A. (1978) Mende Government and Politics under Colonial Rule: a historical study of political change in Sierra Leone, 1890-1937. Freetown: Sierra Leone University Press.

Alldridge, T. J. (1901) The Sherbro and its Hinterland. London: Macmillan.

Alldridge, T. J. (1910) A Transformed Colony: Sierra Leone, as it was and as it is; its progress, peoples, native customs and undeveloped wealth. Philadelphia PA: J. B. Lippincott.

Álvares, M. (1990 [c.1615]) 'Ethiopia Minor and a geographical account of the province of Sierra Leone. An interim translation of Manuel Álvares S. J., "Etiópia Menor e descripção géografica da Província da Serra Leoa." Transcription from an unpublished manuscript by the late Avelino Teixeira da Mota and Luís de Matos'. Translated and introduction by P. E. H. Hair. Liverpool: Department of History, University of Liverpool.

Beatty, K. J. (1915) Human Leopards: an account of the trials of human leopards before the special commission court; with a note on Sierra Leone, past and present. London: Hugh Rees.

Bulte, E., P. Richards and M. Voors (2018) Institutions and Agrarian Development: a new approach to West Africa. New York NY: Palgrave.

Comaroff, J. and J. L. Comaroff (eds) (1993) Modernity and its Malcontents: ritual and power in postcolonial Africa. Chicago IL: University of Chicago Press.

Douglas, M. (1963) The Lele of the Kasai. London: Oxford University Press for the International African Institute.

Douglas, M. (1992) 'Witchcraft and leprosy: two strategies for rejection' in Risk and Blame: essays in cultural theory. London: Routledge.

Douglas, M. (1999a) 'Sorcery accusations unleashed: the Lele revisited, 1987', Africa 69 (2): 177-93.

Douglas, M. (1999b) 'Four cultures: the evolution of a parsimonious model', GeoJournal 47: 411-15. 
Douglas, M. (2001 [1992]) In the Wilderness: the doctrine of defilement in the Book of Numbers. Oxford: Oxford University Press.

Durkheim, E. (1995 [1912]) The Elementary Forms of Religious Life. Translated by K. E. Fields. New York NY: Free Press.

Ferme, M. C. (2001) The Underneath of Things: violence, history and the everyday in Sierra Leone. Berkeley CA: University of California Press.

Fortes, M. and E. E. Evans-Pritchard (eds) (1940) African Political Systems. London: Oxford University Press for the International African Institute.

Fyfe, C. (1962) A History of Sierra Leone. London: Oxford University Press.

Geschiere, P. (1995) The Modernity of Witchcraft: politics and the occult in postcolonial Africa. Charlottesville VA: University of Virginia Press.

Grijspaarde, H., E. Bulte, M. Voors and P. Richards (2013) 'Who believes in witches? Institutional flux in rural Sierra Leone', African Affairs 112 (446): 22-47.

Horton, R. (1985) 'Stateless societies in the history of West Africa' in J. F. A. Ajayi and M. Crowder (eds), History of West Africa: Volume 1. 2nd edition. Harlow: Longman.

James, W. (2003) The Ceremonial Animal: a new portrait of anthropology. Oxford: Oxford University Press.

Jannone, C. (1995) 'Les hommes-leopards et leurs derivés dans la bande dessinée: de la secte-fantasme du colonisateur au people dechu (1930-1991)' in P. Blanchard et al. (eds), L'Autre et Nous. 'Scènes et types: anthropologues et historiens devant le représentations des populations colonisées, des 'ethnies', des 'tribus' et des 'races' depuis les conquêtes coloniales. Paris: ACHAC/Syros.

Jones, A. (1981) 'Who were the Vai?', Journal of African History 22 (2): 159-78. Jones, H. (1987) Mutiny on the Amistad: the saga of a slave revolt and its impact on American abolition, law and diplomacy. New York NY and Oxford: Oxford University Press.

Kalous, M. (1974) Cannibals and Tongo Players of Sierra Leone. Auckland: privately printed.

Laclau, E. (2005) On Populist Reason. London: Verso.

Lynn, M. (1992) 'Technology, trade and a "race of native capitalists": the Krio diaspora of West Africa and the steamship, 1852-95', Journal of African History 33: 421-40.

Middleton, J. F. M. and D. Tait (eds) (1958) Tribes without Rulers: studies in African segmentary systems. London: Routledge and Kegan Paul.

Mokuwa, E., E. Bulte, M. Voors and P. Richards (2011) 'Peasant grievance and insurgency in Sierra Leone: judicial serfdom as a driver of conflict', African Affairs 110 (440): 339-66.

Mudde, C. and C. R. Kaltwasser (2017) Populism: a very short introduction. Oxford: Oxford University Press.

Neuwinger, H. D. (1996) African Ethnobotany: poisons and drugs: chemistry, pharmacology, toxicology. Weinheim: Chapman \& Hall.

Nwaka, G. I. (1986) 'The "leopard" killings of Southern Annang, Nigeria, 194348', Africa 56 (4): 417-40.

Pratten, D. (2007) The Man-leopard Murders: history and society in colonial Nigeria. Edinburgh: Edinburgh University Press.

Reed, T. and J. A. Robinson (2012) 'The chiefdoms of Sierra Leone'. Unpublished report < https://scholar.harvard.edu/files/jrobinson/files/history.pdf>. 
Richards, P. (1985) Indigenous Agricultural Revolution: ecology and food production in West Africa. London: Hutchinson.

Richards, P. (2000) 'Chimpanzees as political animals in Sierra Leone' in J. Knight (ed.), Natural Enemies: people-wildlife conflicts in anthropological perspective. London: Routledge.

Richman, M. H. (2002) Sacred Revolutions: Durkheim and the Collège de Sociologie. Minneapolis MN: University of Minnesota Press.

Ryan, C. (2018) 'Large-scale land deals in Sierra Leone at the intersection of gender and lineage', Third World Quarterly 39 (1): 189-206.

Seligman, A. B., R. P. Weller, M. J. Puett and B. Simon (2008) Ritual and its Consequences: an essay on the limits of sincerity. Oxford and New York NY: Oxford University Press.

Tilley, H. (2011) Africa as a Living Laboratory: empire, development, and the problem of scientific knowledge, 1870-1950. Chicago IL: University of Chicago Press.

Whyte, C. H. (2016) “The strangest problem": Daniel Wilberforce, the human leopard panic and the special court in Sierra Leone' in H. Fischer-Tine (ed.), Anxieties, Fears and Panic in Colonial Settings: empires on the verge of a nervous breakdown. Basingstoke: Palgrave Macmillan.

\begin{abstract}
Demonization is a widespread aspect of political discourse. We are familiar with the demonization of Brussels bureaucrats as a tool for pursuing the British exit from the European Union, and we take stories about the compulsory straightening of bananas with a pinch of salt, however frustrating it might be that some disaffected voters choose to accept these canards as true. But somehow, stories about the demonic in Africa have been accorded much greater ontological respect, not only by colonial powers keen to boost their own legitimacy through claims to a civilizing mission, but also by anthropologists anxious to understand their informants' imaginative concerns, perhaps without fully appreciating the political craft or guile with which these discourses are invested. In seeking to void the charge of delusion, an empathetic reading of demonization risks missing the strategic significance of mythic interventions intended to extract political advantage. This article examines an instance of mythic creativity in the politics of late nineteenth-century interior Sierra Leone as an example of the stagecraft sometimes implicit in African public authority. The case is that of the human leopard, an avatar of commercially compromised chieftaincy. The article asks whether the alleged activities of these leopards were the straight bananas of a certain form of anti-colonial political resistance. In a concluding discussion, some consequences for understanding current forms and practices of local public authority are inferred.
\end{abstract}

\title{
Résumé
}

La diabolisation est un aspect courant du discours politique. Celle des bureaucrates de Bruxelles nous est familière, utilisée comme outil de soutien au retrait britannique de l'Union européenne. Nous accueillons avec scepticisme des histoires comme celle de la réglementation européenne imposant des bananes droites, même s'il peut être frustrant de constater que certains électeurs 
désabusés croient en la véracité de ces euromythes. Mais assez curieusement, les histoires de démons en Afrique se sont vues accorder bien plus de respect ontologique, non seulement de la part des puissances coloniales désireuses de renforcer leur propre légitimité en arguant d'une mission civilisatrice, mais aussi de la part des anthropologues soucieux de comprendre les préoccupations imaginatives de leurs informateurs, peut-être sans apprécier pleinement l'habileté ou la ruse politique dont sont empreints ces discours. En cherchant à rendre caduque l'accusation de fantasme, une lecture empathique de la diabolisation risque de ne pas percevoir l'importance stratégique des interventions mythiques destinées à tirer un avantage politique. Cet article examine un cas de créativité mythique dans la politique de la Sierra Leone intérieure au dix-neuvième siècle, comme exemple d'art de la mise en scène parfois implicite dans l'autorité publique africaine. Ce cas est celui de l'homme-léopard, un avatar de chefferie commercialement compromise. L'article se demande si les activités présumées de ces léopards étaient les bananes droites d'une certaine forme de résistance politique anticoloniale. Dans une discussion de conclusion, l'auteur en déduit des conséquences pour la compréhension de formes et de pratiques actuelles d'autorité publique locale. 